\title{
SPITTLEBUG INFESTATION IN SUGARCANE AFFECTS ETHANOLIC FERMENTATION
}

\author{
Gisele Cristina Ravaneli ${ }^{1}$; Leonardo Lucas Madaleno${ }^{1}$; Leandro Eduardo Presotti ${ }^{1}$; Miguel \\ Angelo Mutton²; Márcia Justino Rossini Mutton ${ }^{1 *}$ \\ ${ }^{1}$ UNESP/FCAV - Depto. de Tecnologia, Via de Acesso Prof. Paulo Donato Castellane s/n - 14884-900 - \\ Jaboticabal, SP - Brasil. \\ ${ }^{2}$ UNESP/FCAV - Depto. de Produção Vegetal. \\ *Corresponding author <mjrmut@fcav.unesp.br>
}

\begin{abstract}
The spittlebug (Mahanarva fimbriolata) has become a key pest of the sugarcane crop in Brazil with the increase of green-cane harvesting, causing stalk yield and cane quality losses. This research was undertaken to evaluate the effects of the spittlebug (Mahanarva fimbriolata) on cane quality and juice fermentation. The experiment was arranged in a completely randomized $5 \times 2$ factorial design, with five spittlebug infestation levels $\left(0-0.5 ; 0.6-2.5 ; 2.6-5 ; 5.1-8 ; 8.1-12.5\right.$ nymphs $\left.\mathrm{m}^{-1}\right)$, controlled or not with thiamethoxam $\left(0.2 \mathrm{~kg}\right.$ of active ingredient ha $\left.{ }^{-1}\right)$. To conduct fermentation, Saccharomyces cerevisiae (fresh and pressed baker's yeast) was inoculated to musts at a concentration of $30 \mathrm{~g} \mathrm{~L}^{-1}$. Microbiological analyses were performed at the beginning, middle and end of the fermentation process. The alcohol content and total residual reducing sugars were measured in the wine. Spittlebug attack influenced negatively sugarcane quality, yeast cell and bud viability, and wine alcohol content. Insecticide application resulted in higher cane quality and cell and bud viabilities, resulting in increased fermentation yield.
\end{abstract}

Key words: Saccharum spp., Mahanarva fimbriolata, fermentation process, ethanol production

\section{A INFESTAÇÃO DE CIGARRINHA-DAS-RAÍZES EM CANA-DE-AÇÚCAR AFETA A FERMENTAÇÃO ETANÓLICA}

\begin{abstract}
RESUMO: A cigarrinha-das-raízes (Mahanarva fimbriolata) tornou-se praga-chave na cultura da canade-açúcar com a expansão das áreas de colheita sem queima, comprometendo a produtividade e a qualidade da matéria-prima e consequentemente o processamento industrial. Essa pesquisa objetivou avaliar os efeitos da cigarrinha-das-raízes (Mahanarva fimbriolata) sobre a qualidade da cana-de-açúcar e a fermentação do caldo. $\mathrm{O}$ delineamento experimental utilizado foi inteiramente casualizado, em esquema fatorial $5 \times 2$, sendo cinco níveis iniciais de infestação da cigarrinha-das-raízes (0-0,5; 0,6-2,5; 2,6-5; 5,1-8; 8,1-12,5 ninfas $\left.\mathrm{m}^{-1}\right)$, controlados ou não com o inseticida thiamethoxam $\left(0,2 \mathrm{~kg}\right.$ de ingrediente ativo ha $\left.{ }^{-1}\right)$. Para a fermentação alcoólica, o fermento prensado Saccharomyces cerevisiae foi inoculado aos mostos na concentração de $30 \mathrm{~g} \mathrm{~L}^{-1}$. As analises microbiológicas foram realizadas no início, meio e final do processo. O teor alcoólico e os açúcares redutores residuais totais foram analisados nos vinhos. $\mathrm{O}$ ataque da cigarrinhadas-raízes influenciou negativamente a qualidade da cana-de-açúcar, viabilidade celular e de brotos de leveduras e o teor alcoólico dos vinhos. A aplicação do inseticida controlou a praga e resultou em melhor qualidade da cana, viabilidade de células e brotos de leveduras, aumentando a produção de etanol.

Palavras-chave: Saccharum spp., Mahanarva fimbriolata, processo fermentativo, produção de etanol
\end{abstract}

\section{INTRODUCTION}

Sugarcane (Saccharum spp.) is one of the most important crops in Brazil, grown for raw material of several industrial products. Among these products is ethanol, which is becoming more important over the past years because of its use as renewable fuel source. The fermentation is a key step in ethanol production, during which yeast cells transform substrate sugars into ethanol, $\mathrm{CO}_{2}$ and secondary compounds. This process is influenced by cane quality, which depends on sug- arcane variety, environment conditions, ripening stage, pests and diseases (Mutton \& Mutton, 2002).

The spittlebug Mahanarva fimbriolata (Stål, 1854) (Hemiptera: Cercopidae) has become a key pest of the sugarcane crop in Brazil, because the soil moisture and temperature conditions provided by the litter left on the field after harvest without previous trash burn are favorable for the development of the insect. Nymphs suck on roots while adults on suck leaves, resulting in nutrient deficiency, thin and dry stalks, affecting both stalk and sugar yield (Mendonça et al., 
1996). The damages may be severe for most sugarcane genotypes, especially middle and end of season varieties (Dinardo-Miranda et al., 1999). Metabolic alterations take place in the sugarcane in response to spittlebug infestation, producing a wide variety of organic acids and phenolic compounds. These substances reduce sugar recovery, yeast metabolism during fermentation, decrease ethanol yield, and alter the composition of the final products (Mutton \& Mutton, 2002).

$M$. fimbriolata can be controlled biologically, with pesticides (Dinardo-Miranda et al., 2000a) or by cultural practices like removing the litter from the rows (Dinardo-Miranda et al., 2004). Previous studies report that an efficient control of this pest significantly increases cane quality (Dinardo-Miranda et al., 1999), and that this improvement may reflect on fermentation yield.

This research was carried out determine the effects of M. fimbriolata and its chemical control on cane quality, fermentation microorganisms and ethanol production.

\section{MATERIAL AND METHODS}

\section{Experimental conditions}

The experiment was set in a sugarcane field harvested with no trash burn, in Jaboticabal-SP ( $21^{\circ} 15^{\prime} 22^{\prime \prime}$ S; $48^{\circ} 18^{\prime} 58^{\prime \prime} \mathrm{W}$ ), during the $2003 / 2004$ season. The sugarcane variety SP80-1816 ( ${ }^{\text {rd }}$ ratoon), which is susceptible to $M$. fimbriolata (DinardoMiranda et al., 2000a) was initially established on sixty plots, comprising two $4 \mathrm{~m}$ rows, spaced $1.5 \mathrm{~m}$, with plots $6 \mathrm{~m}$ apart of each other. In 2003, the first occurrence of spittlebug nymphs was observed on December 12, when plants were five months old. After this observation, thirty plots were selected with the following initial infestation levels: $0-0.5 ; 0.6-2.5 ; 2.6-5.0$; $5.1-8.0 ; 8.1-12.5$ nymphs $\mathrm{m}^{-1}$. Six replicates were used and the nymph count was performed by removing the litter, counting nymphs and replacing the litter. On December 30 , thiamethoxam $(0.2 \mathrm{~kg}$ active ingredient $\mathrm{ha}^{-1}$ ) was applied with a pressurized sprayer at constant pressure to three plots of each infestation level. These plots represented treated and non-treated replicates for each initial infestation level. Population levels were monthly monitored by counting nymphs in the soil until March, which corresponds to the end of the rainy season, when $M$. fimbriolata egg diapause starts.

In July 2004, ten stalks per plot were sequentially harvested from each row, defoliated and topped at the apex bud line. The juice was extracted as recommended by Tanimoto (1964).

The experiment was arranged in a $5 \times 2$ factorial as a completely randomized design. Treatments corresponded to the spittlebug infestation levels (fac- tor A) and pesticide applications (control and insecticide treated, factor B). Microbiological and technological analyses were performed with two and three replications, respectively. Data were submitted to the ANOVA and linear regression and means were compared by Tukey test at $5 \%$.

\section{Technological analysis}

The extracted juice was analyzed for sucrose content (pol) (Scheneider, 1979), purity (CONSECANA, 2004), reducing sugars (Lane \& Eynon, 1934), total phenolic compounds (Folin \& Ciocalteau, 1927). Total juice acidity was analyzed by titration with $\mathrm{NaOH} 0.05 \mathrm{~N}$, and $\mathrm{pH}$ was analyzed using a digital $\mathrm{pHmeter}$.

\section{Fermentation process}

The fresh baker's yeast (Saccharomyces cerevisiae) was used at a concentration of $30 \mathrm{~g}$ of yeast per liter of must $\left(20.2 \times 10^{8} \mathrm{cel} \mathrm{mL}^{-1}\right)$. Musts $(500 \mathrm{~mL})$ were prepared with the sugarcane juices of all treatments at $14^{\circ}$ Brix and pH $3.5( \pm 0.2)$ (Gonçalves, 2003) and fermentations were conducted in $1 \mathrm{~L}$ erlenmeyers, in a BOD incubator set at $29^{\circ} \mathrm{C}$, monitoring the process with the help of a Brix densimeter. The end of fermentation was established as ten hours after inoculation, when the level of soluble solids was lower than $1{ }^{\circ}$ Brix. After fermentation, wines were centrifuged $\left(16900 \times \mathrm{g}, 5\right.$ minutes, $\left.25^{\circ} \mathrm{C}\right)$ to separate yeast cells.

\section{Technological and microbiological analyses}

At the beginning ( $\mathrm{T}_{\mathrm{o}}, 40$ minutes after inoculation), middle (Tm, 5 hours after) and end of the fermentation process $\left(\mathrm{T}_{\mathrm{f}}\right)$, cell and bud viability and bacterial concentration analyses were performed (Lee et al., 1981). Wines were analyzed for alcohol content by a digital densimeter (after 1:1 dilution with water), and total residual reducing sugars (Lane \& Eynon, 1934).

\section{RESULTS AND DISCUSSION}

Thiamethoxam efficiently controlled $M$. fimbriolata (Figure 1). In plots where the pesticide was applied there was a reduction in population levels, and the second infestation peak after January which occurred in non-treated plots was not observed. These results are in accordance to previous studies (DinardoMiranda et al., 2000a; 2003), which also show higher efficiency of chemical control in comparison to biological control or cultural practices, especially at infestation levels higher than 2 nymphs $\mathrm{m}^{-1}$. The non-occurrence of the second infestation peak of $M$. fimbriolata nymphs may be explained by the residual effect of the pesticide, which lasts approximately 120 days in the field (Dinardo-Miranda, 2003). 

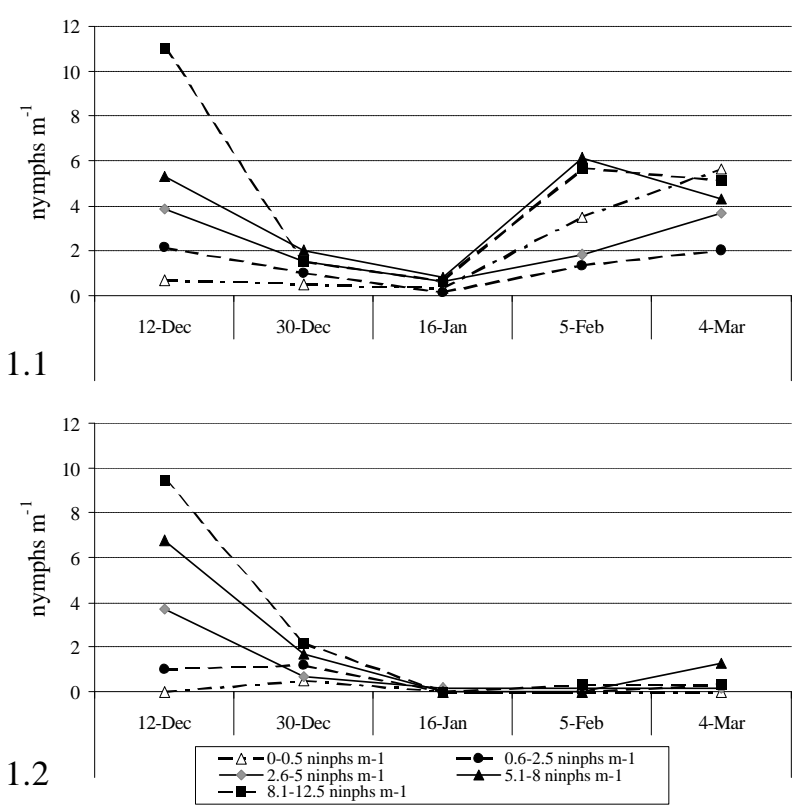

Figure 1 - Population variation of $M$. fimbriolata nymphs in sugarcane roots from December 2003 to March 2004. 1.1-Control. 1.2-Thiamethoxam $(0.2 \mathrm{~kg}$ of active ingredient $\mathrm{ha}^{-1}$ ).

Yeast cell viability was lower in higher infestation levels, especially after the middle of the fermentation process (Figure 2). The decrease in cell viability is due to several factors, such as nutrient availability and bacterial contamination, which result from cane deterioration. Previous studies found similar results (Gonçalves, 2003) wich were associated with a decrease in cane quality under spittlebug infestation (Dinardo-Miranda et al., 1999; 2000b; 2002). The same association can be made in this study, which shows significant sucrose level reductions and increased total acidity and phenolics in the sugarcane juice associated with M. fimbriolata populations (Figure 3).

Phenolics are known to negatively affect yeast metabolism during fermentation (Polakovic et al., 1992; Narendranath et al., 2001). A less sharp decrease in cell viability was observed when M. fimbriolata was controlled (Figures 2.2 and 2.3), showing the negative impact of spittlebug attack on the performance of the fermentation yeasts. This effect became more evident from the second $M$. fimbriolata infestation level on (data not shown), confirming that the cane quality increase due to spittlebug control favors the maintenance of viable yeast cells during ethanolic fermentation.

Infestation levels affect on bud viability, even at the beginning of fermentation (Figure 4), which also seems to be due to cane deterioration. The rate of viable cells and buds during fermentation is important to keep yeast population levels, and often reflect on the fermentation yield.
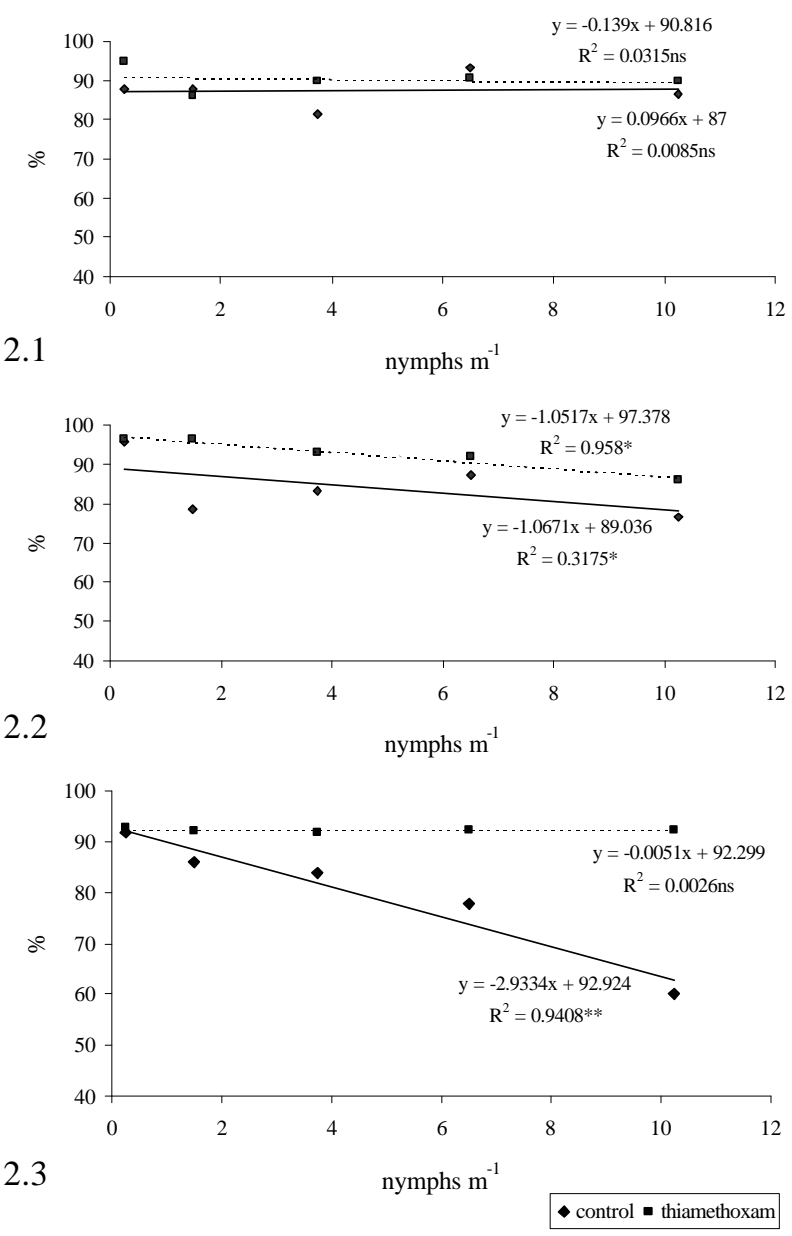

Figure 2 - Yeast cell viability during the fermentation process under M. fimbriolata infestation. 2.1- Beginning; 2.2Middle; 2.3- End of fermentation.

Similarly to cell viability, a less steep reduction in bud viability was observed during fermentation when M. fimbriolata was controlled (Figure 4) probably because of the increased cane quality caused by the pest control.

The highest yeast cell and bud viability rates were observed at the beginning of the fermentation process. The reduction of viable cells as the fermentation goes on is due to an increase in the concentration of ethanol, $\mathrm{CO}_{2}$ and acidity, and a reduction of sugar levels in the wine during fermentation. The intracellular accumulation of ethanol and other metabolites favors the decrease of live yeast cells (Stokes, 1971; Hallsworth, 1998). This reduction often takes place in industrial conditions without affecting fermentation conduction and viability (Mutton, 1998). Considering that in Brazil ethanolic fermentations yeasts are reused in fermentation cycles, it is extremely important to have viable cells and buds at the end of each cycle. 

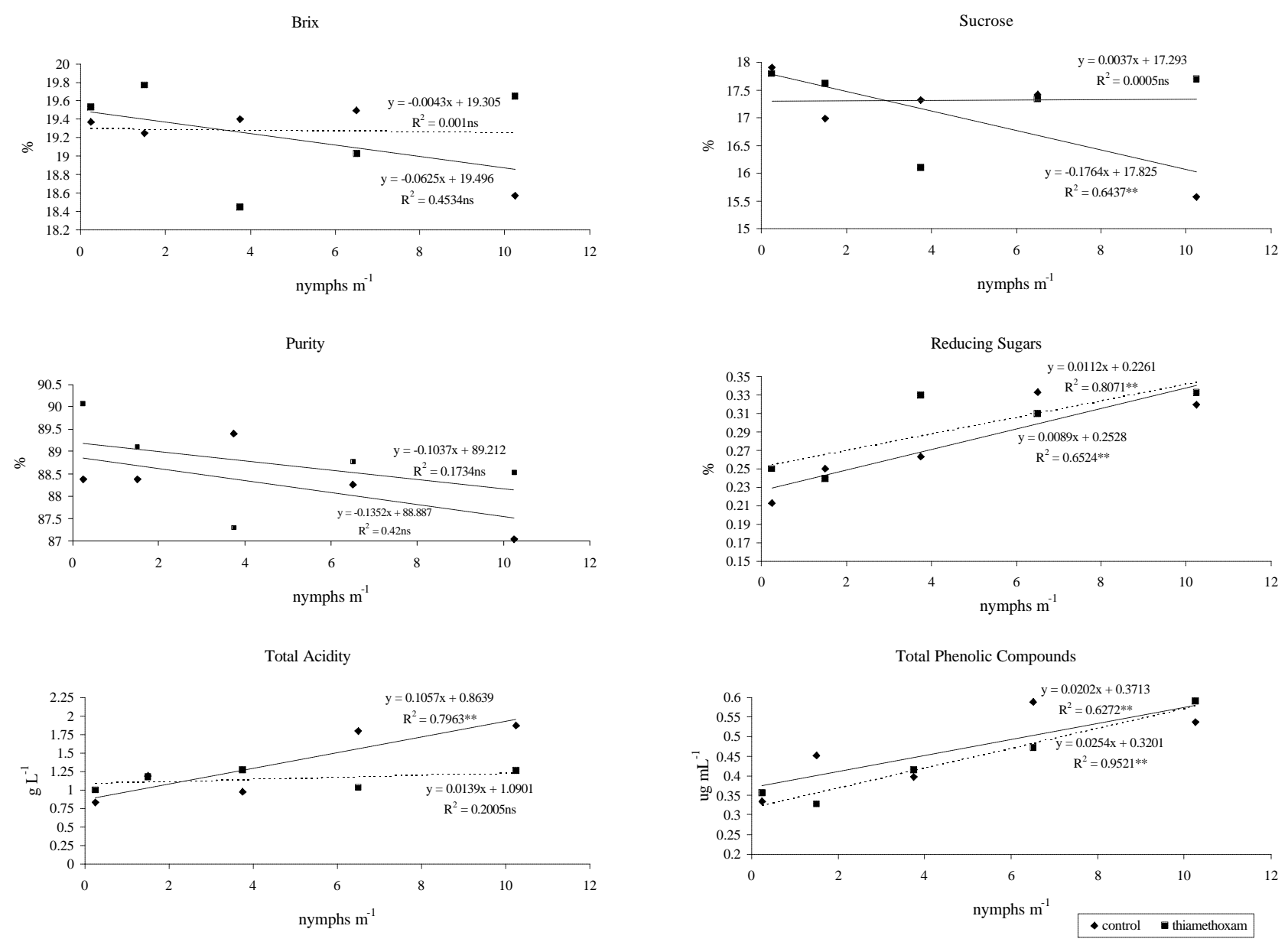

Figure 3 - Technological analysis of the sugarcane juice under M. fimbriolata infestation.

The main source of sugarcane juice contamination is the field because soil microorganisms find wide and favorable conditions for their development in sugarcane stalks, resulting in highly contaminated sugarcane juices (Stupiello \& Horii, 1981). Another factor that counts for increasing contamination in fermentation is the quality of the raw material. Spittlebug infestation caused no effect on bacterial concentration in the beginning and middle of the fermentation (Figure 5), showing that a decrease on yeast performance may be more related to cane quality parameters than on microbiological deterioration. This result agrees with previous studies (Gonçalves, 2003), which reported that sometimes the loss of quality is not related to bacterial contamination, but due to a biochemical reaction of plants against pests, which use part of the sugar stored in stem parenchyma cells to provide carbon and energy for the biosynthesis of defense-related metabolites. However, further investigation is necessary to confirm this hypothesis.

At the end of the fermentation process, an increase in bacterial contamination was observed, pos- sibly favored by a higher amount of residual sugars combined with a low viability of yeast cells.

The attack of $M$. fimbriolata resulted in higher levels of total residual reducing sugars in the wine (Table 1), reflecting in alcohol yield decrease. In response to spittlebug infestation, sugarcane defense mechanisms may produce lignin, phenolic compounds (Mutton, 2003) and other metabolites. As in other studies on plant defense against pests and diseases (Phelps \& Young, 1996; Fontaniella et al., 2003), this study showed an increase in the level of total phenolics in sugarcane juice (Figure 3). In the presence of phenolics, yeast invertase activity is reduced (Polakovic et al., 1992), resulting in yeast population decrease and even fermentation inhibition. Phenolic compounds possibly played a negative role on yeast physiology during fermentation, which resulted in cell and bud viability reduction. As a consequence, there was an increase of total residual reducing sugars and alcohol content.

A decrease in the wine alcohol content was observed from the second to the highest infestation level (Table 1). This is an expected result, since the attack of spittlebugs negatively influenced yeast performance 

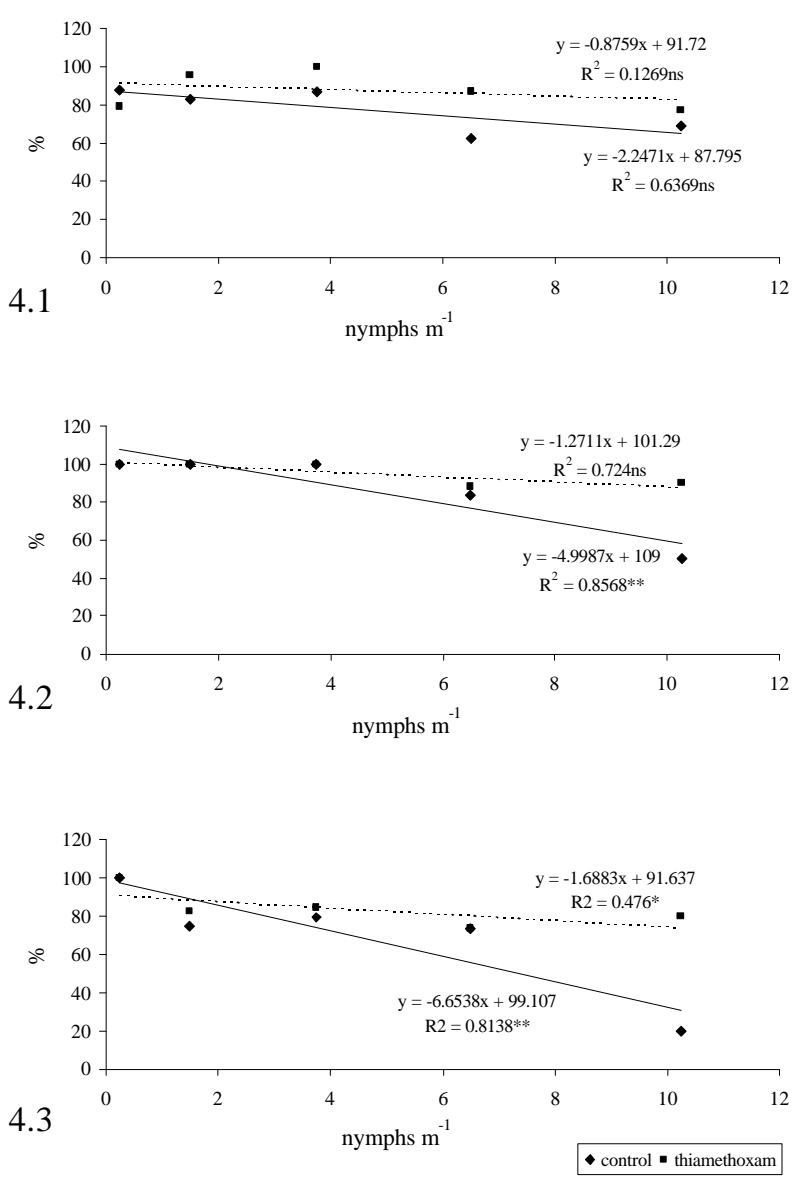

Figure 4 - Yeast bud viability during the fermentation process in juices from sugarcane under $M$. fimbriolata infestation. 4.1- Beginning; 4.2- Middle; 4.3- End of fermentation.

Table 1 - Effect of $M$. fimbriolata infestation levels on total residual reducing sugars and alcohol contents in wines.

\begin{tabular}{|c|c|c|}
\hline & $\begin{array}{c}\text { Residual Reducing } \\
\text { Sugars }\end{array}$ & $\begin{array}{l}\text { Alcohol } \\
\text { Content }\end{array}$ \\
\hline & $\%$ & $\% \mathrm{v} \mathrm{v}^{1}$ \\
\hline \multicolumn{3}{|l|}{ Nymphs $m^{-1}(\mathrm{~N})$} \\
\hline 0 to 0.5 & $0.0575 \mathrm{~B}$ & $6.9 \mathrm{~A}$ \\
\hline 0.6 to 2.5 & $0.2107 \mathrm{~A}$ & $6.4 \mathrm{~B}$ \\
\hline 2.6 to 5,0 & $0.1553 \mathrm{AB}$ & $6.15 \mathrm{~B}$ \\
\hline 5.1 to 8.0 & $0.1567 \mathrm{~A}$ & $6.30 \mathrm{~B}$ \\
\hline 8.1 to 12.5 & $0.1643 \mathrm{~A}$ & $6.34 \mathrm{~B}$ \\
\hline $\mathrm{F}$ Test $(\mathrm{N})$ & $6.463 * *$ & $6.452 * *$ \\
\hline LSD (Tukey) & 0.0813 & 0.472 \\
\hline \multicolumn{3}{|l|}{ Treatments (T) } \\
\hline control & $0.17 \mathrm{~A}$ & $6.15 \mathrm{~B}$ \\
\hline thiamethoxam & $0.14 \mathrm{~A}$ & $6.68 \mathrm{~A}$ \\
\hline F Test $(\mathrm{T})$ & $2.381 \mathrm{~ns}$ & $28.163 * *$ \\
\hline LSD (Tukey) & 0.0359 & 0.208 \\
\hline $\mathrm{F}$ Test $(\mathrm{N} \times \mathrm{T})$ & $3.517 *$ & $1.228 \mathrm{~ns}$ \\
\hline $\mathrm{CV}(\%)$ & 30.89 & 4.26 \\
\hline
\end{tabular}

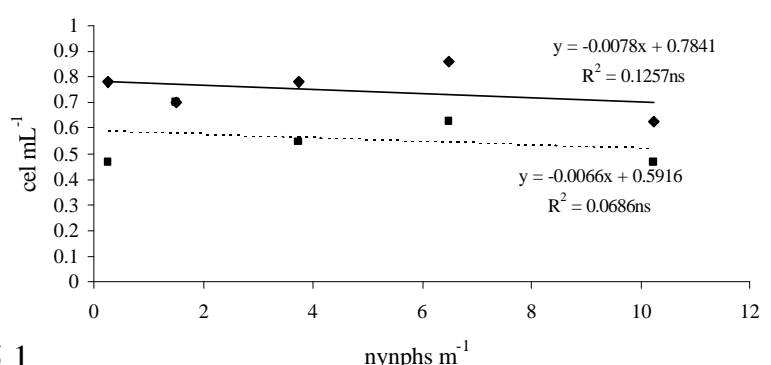

5.1
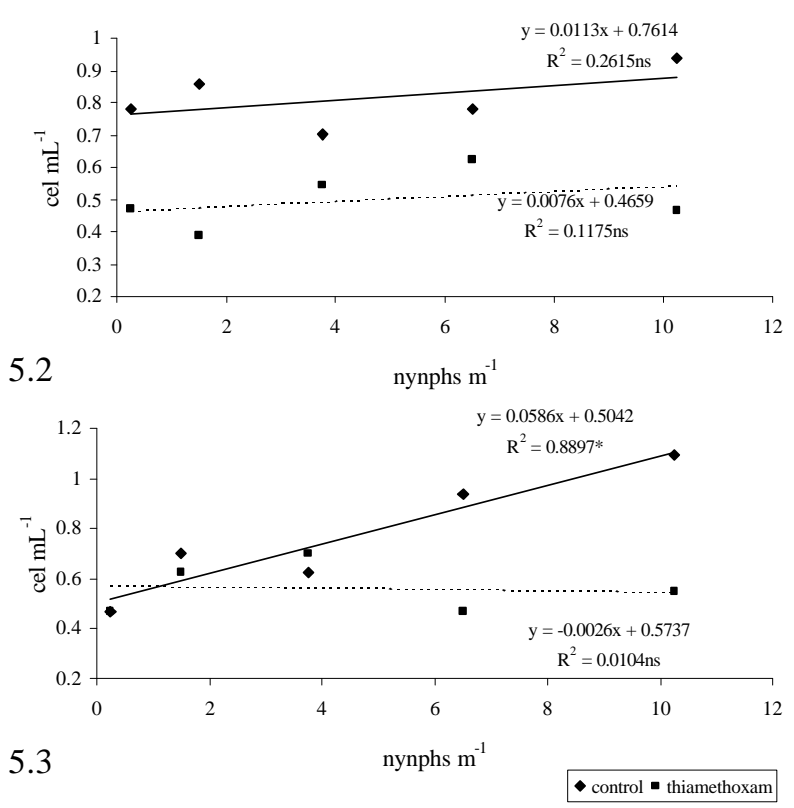

Figure 5 - Bacterial contamination during the fermentation process in juices from sugarcane under $M$. fimbriolata infestation. 5.1- Beginning; 5.2- Middle; 5.3- End of fermentation.

during fermentation (Figures 2 and 4). Also, when thiamethoxam was applied, the alcohol content was higher, evidencing the importance of a high quality cane for fermentation. These results are in accordance with Gonçalves (2003), who showed that less damaged the sugarcane, increase the level of sugars and fermentation yield.

\section{CONCLUSIONS}

- Spittlebug infestation negatively influences the sugarcane juice fermentation process.

- The efficient control of this pest improves cane quality, which reflects in a better fermentation process.

- The yeast cell and bud viability decrease may be due to defense metabolites that the sugarcane plant produces against $M$. fimbriolata, like organic acids and phenolic compounds.

\section{ACKNOWLEDGEMENTS}

To Usina São Carlos - Coinbra, for providing the sugarcane and for their help with experiment con- 
duction, and Syngenta Proteção de Cultivos Ltda. for financial support. To Eduardo Rossini Guimarães for his helpful suggestions and critical review of the manuscript. Gisele Cristina Ravaneli and Leonardo Lucas Madaleno are CNPq scholar. Leandro Eduardo Presotti is a CAPES' scholar.

\section{REFERENCES}

CONSECANA. Normas de avaliação da qualidade da cana-deaçúcar. 2004. Disponível em: http://www.unica.com.br/files/ consecana/normaseprecos.pdf. Acesso em: 21 set. 2004.

DINARDO-MIRANDA, L.L. Cigarrinha-das-raízes em cana-deaçúcar. Campinas: Instituto Agronômico, 2003. 72p.

DINARDO-MIRANDA, L.L.; FIGUEIREDO, P.; LANDELL, M.G.A.; FERREIRA, J.M.G.; CARVALHO, P.A.M. Danos causados pelas cigarrinhas-das-raízes (Mahanarva fimbriolata) a diversos genótipos de cana-de-açúcar. Stab: Açúcar, Álcool e Subprodutos, v.17, p.48$52,1999$.

DINARDO-MIRANDA, L.L.; FERREIRA, J.M.G.; DURIGAN, A.M.P.R.; BARBOSA, V. Eficiência de inseticidas e medidas culturais no controle de Mahanarva fimbriolata em cana-de-açúcar. Stab: Açúcar, Álcool e Subprodutos, v.18, p.34-36, 2000a.

DINARDO-MIRANDA, L.L.; FERREIRA, J.M.G.; CARVALHO, P.A.M. Influência da cigarrinha-das-raízes, Mahanarva fimbriolata, sobre a qualidade tecnológica da cana-de-açúcar. Stab: Açúcar, Álcool e Subprodutos, v.19, p.34-35, 2000b.

DINARDO-MIRANDA, L.L.; GARCIA, V.; PARAZZI, V.J. Efeito de inseticidas no controle de Mahanarva fimbriolata (Stal) (Hemiptera: Cercopidae) e de nematóides fitoparasitos na qualidade tecnológica e na produtividade da cana-de-açúcar. Neotropical Entomology, v.31, p.909-914, 2002.

DINARDO-MIRANDA, L.L.; NAKAMURA, G.; ZOTARELLI, L.; BRAZ, B.A.; EUZEBIO, O. Viabilidade técnica e econômica de Actara 250WG, aplicado em diversas doses, no controle da cigarrinha-das-raízes. Stab: Açúcar, Álcool e Subprodutos, v.22, p.39-43, 2003.

DINARDO-MIRANDA, L.L.; COELHO, A.L.; FERREIRA, J.M.G., Influência da época de aplicação de inseticidas no controle de Mahanarva fimbriolata (Stal) (Hemiptera:Cercopidae), na qualidade e produtividade da cana-de-açúcar. Neotropical Entomology, v.33, p.92-98, 2004.

FOLIN, O.; CIOCALTEAU, V. On tyrosine and tryptophane determinations in proteins. The Journal of Biological Chemistry, v.7, p.101-120, 1927.

FONTANIELLA, B.; VICENTE, C.; LEGAZ, M.E.; ARMAS, R. de; RODRIGUEZ, C.W.; MARTINEZ, M.; PINÕN, D.; ACEVEDO, R.; SOLAS, M.T. Yellow leaf syndrome modifies the composition of sugarcane juices in polysaccharides, phenols and polyamines. Plant Physiology Biochemistry, v.41, p.1027-1036, 2003.
GONÇALVES, T.D. Danos causados por Mahanarva fimbriolata em cana-de-açúcar: reflexos na qualidade da matéria-prima e fermentação etanólica. Jaboticabal: FCAV/UNESP, 2003. 51p. (Dissertação Mestrado).

HALLSWORTH, J.E. Ethanol-induced water stress in yeast. Journal of Fermentation Bioengineering, v.85, p.125-137, 1998.

LANE, J.H.; EYNON, L. Determination of reducing sugars by Fehling solution with methylene blue indicator. London: Norman Rodger, 1934. 8p.

LEE, S.S.; ROBINSON, F.M.; WONG, H.Y. Rapid determination of yeast viability. Biotechnology Bioengineering Symposium, n.11, p.641-649, 1981

MENDONÇA, A.F.; BARBOSA, G.V.S.; MARQUES, E.J. As cigarrinhas da cana-de-açúcar (Hemiptera: Cercopidae) no Brasil. In: MENDONÇA, A.F. (Ed.). Pragas da cana-de-açúcar. Maceió: Insetos \& Cia,1996. 200p.

MUTTON, M.J.R. Avaliação da fermentação etanólica do caldo de canade-açúcar (Saccharum spp) tratadas com maturadores químicos. Jaboticabal: FCAV; UNESP, 1998. 178p. (Tese - Livre Docência).

MUTTON, M.J.R. Reflexos da qualidade da matéria-prima no processo industrial. In: SIMPÓSIO INTERNACIONAL DA STAB, 3., Águas de São Pedro, 2003. Perdas de açúcares: do campo ao produto final. Águas de São Pedro: STAB, 2005. 1 CD ROOM.

MUTTON, M.J.R.; MUTTON, M.A. Maturadores químicos em canade-açúcar: III - Efeitos na fermentação etanólica e microbiota do mosto. In: CONGRESSO NACIONAL DA STAB,8., Recife, 2002. Anais. Recife: STAB, 2002. p.452-457.

NARENDRANATH, N.V.; THOMAS, K.C.; INGLEDEW, W.M. Effects of acetic acid ad lactic acid on the growth of Saccharomyces cerevisiae in a minimal medium. Journal of Industrial Microbiology and Biotechnology, v. 26, p.171-177, 2001.

PHELPS, C.D.; YOUNG, L.Y. Microbial metabolism of the plant phenolic compounds ferulic and syringic acids under three anaerobic conditions. Microbial Ecology, v.33, p.206-215, 1996.

POLAKOVIC, M.; HANDRIKOVÁ, G.; KOSIK, M. Inhibitory effects of some phenolic compounds on enzymatic hydrolysis of sucrose. Biomass and Bioenergy, v.3, p.369-371, 1992.

SCHNEIDER, F. Sugar analysis: ICUMSA methods. Peterborough: ICUMSA, 1979, 265p.

STOKES, J.L. Influence of temperature on the growth and metabolism of yeast. In: ROSE, A.H.; HARRISON, J. S. (Ed.). The yeast. New York: Academic Press, 1971. p.119-134.

STUPIELLO, J.P.; HORII, J. Condução da fermentação alcoólica. Saccharum, v.17, p.43-46, 1981.

TANIMOTO, T. The press method of cane analysis. Hawaiian Planter's Record, v.57, p.133-150, 1964.

Received April 04, 2006

Accepted October 16, 2006 